\title{
Post-critical writing praxis as a qualitative researcher
}

\section{Dr Juliet Henderson, Oxford Brookes University}

\section{Abstract}

The intention of this paper is to unsettle our habits of scholarly writing and reading, from within the grids of intelligibility of Western, rationalist materiality, so as to make visible what we/I no longer often see: the academic writing and publishing constraints that discipline our assemblages of knowledge. Taking poststructuralist articulations of the 'critical' and 'ethical' as heuristics for developing a praxis of critical deconstructive authoring, where agency is coterminous with, not external to, the event of writing, it puts to work Foucault's perspective that the subject is a form, not a substance, (Foucault 1984, p.290) to explore one way of crafting 'an academic subject yet to come' (Ball 2016, p.2). Beginning with a brief consideration of the normative mechanisms that govern scholarly writing, it then uses some of the conceptual tools of Foucault, Derrida and Spivak to unfold and vindicate spaces in the grids of governance for reforming the subject.

KEY WORDS Western, rationalist materiality, writing praxis, qualitative research, deconstructive authoring

\section{AGENCY OF DISCOURSE I}

\section{Cracking open the human sciences}

To be clear at the outset, I do not understand the 'critical' in scholarly writing to refer solely to argumentation or reasoning, nor do I see it as one thing or another. My understanding of 'criticality' in this paper emerges from poststructuralist and deconstructive theoretical concepts and procedures, which see it as something we do or have done to us. In an age of ever greater pressure upon academics to shape their research to fit different narrow regularities of neoliberal 'excellence' premised on audit culture and market based values (Readings 1996; Ball 2016; Hannam 2009), I consider these far from obsolete in revealing to us how governance can blind us to the multiple gaps and folds in the fabric of humanist scientific knowledge we relegate to the margins. Thus, I take as my starting point a Foucaultian practice of ethical care of the self that conforms to yet resists governance (Foucault 1987). This is allied with a passionate interest in ways the semiotic and bodily resources 'I', 'we' and 'you' deploy as academic knowers can fashion a less reductive, less certain, more historical representation of knowledge than that produced by Western traditions of rational examination.

Agency of discourse II

Agency of discourse III

Transformation of writing practices can be seen everywhere. A historically potent field for radical change in written genre and style is, of course, literary and poetic creation. Three examples that spring to mind in the modernist English language canon are first James Joyce's Ulysses, in which he opens up the problem of the normative in fiction by drawing on countless historical styles to retell the story of Homer's Odyssey in his contemporary Ireland. Second, e.e. cummings who freed poetry from the tyranny of punctuation and capital letters. Third, Virginia Woolf and streamof-consciousness.

More broadly, the constant

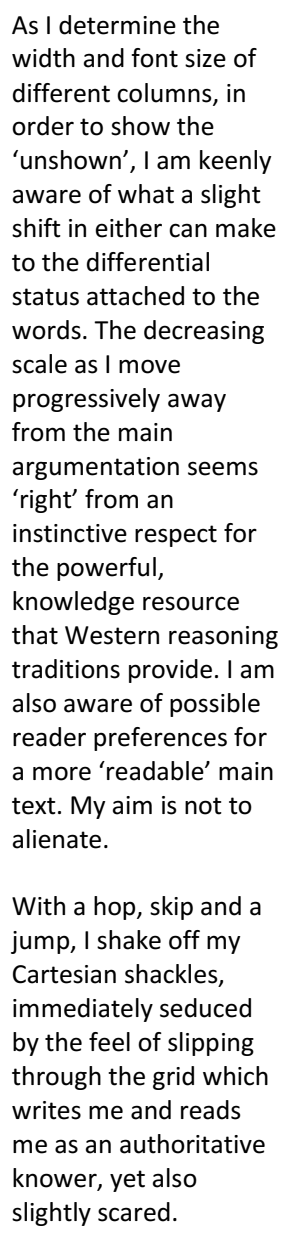

With a hop, skip and a jump, I shake off my

Cartesian shackles, immediately seduced by the feel of slipping through the grid which writes me and reads me as an authoritative knower, yet also slightly scared. 
By mediating what such an account might look like in my writing, my aim is to honour the creative, critical traditions of scientific inquiry yet simultaneously interrupt the hegemonic, linear practices in academic rhetoric, to keep them open to the unspoken, invisibilised historical contingencies of knowledge production we suppress to be seen. Similarly, I am conscious of Lather's call to 'imagine forward' (2013, p.634) our ways of accomplishing an inquiry in which we are comfortable with 'the insecurity of knowing' (Lather 2012, p.640). Whilst her imagining conceptualises a post-qualitative methodology, this imagining grasps at a post-qualitative scholarly writing practice.

As one radical researcher among many, if I am to conduct practices commensurate with the epistemologies and ontologies of poststructuralist and deconstructive theory, I need textual practices that resist fictions of a transcendental position of universal authority that claim to provide 'rigour' and 'validity' to most academic discourse. I/we need textual practices akin to Foucault's view of writing as 'the practice of freedom' (Foucault 1984, p.284) that re-orient the always-already epistemologies, rhetorical moves and genre of Western, essayist linear reasoning. These perpetuate rather than cut through dichotomies such as 'objective' and 'subjective', 'science' and 'humanities', and 'Big Data' and 'small data', and so fail to resolve a tension between the theories underpinning interpretive, post-critical qualitative research and its written application as social critique.

Resistance to dominant knowledge formats is not new. As Pascale (2016, p.219) puts it, 'an insurrection against the hegemonic construction of science has been underway since the 1960s'. This targets the 'processes of formalization' (Pascale 2016, p.223) that constrain scholarship, and perpetuate ahistorical, Cartesian accounts of knowledge. To give a brief flavour of ways researchers have approached sought to decouple qualitative research from fixed notions of context and experiment to open up the process of inquiry, I here discuss a few that set the scene for this this paper's sensitivities to difference, and its historicization of marginal con-texts of knowledge production, otherwise hidden from view. change in technologies of writing and communication multiply new norms and practices which transgress and meander away from the syntactic and semantic logics of authoritative texts. Certain disciplines, such as ethnography, have drawn from the literary to bring out e.g. 'voice' in the text, akin to what Jakobson calls the 'poetic function', which embodies the orality and sound of language independently of its referential function (Jakobson cited in Hébert 2011). Yet notions of 'voice' crumble too in the ruins of knowledge.
I see the term postcritical as synonymous with activism from within and between the workings of our own uncertain textual practices.

cutting into pages surfaces other parts of practices we are party to and are part of us 
An early reconceptualization of the theorypractice divide produced by science's selfproclaimed golden standard processes of verification, was Glaser and Strauss's grounded theory (1967), which aimed to unfreeze theory from its status as an ahistorical tool of deductive scientific inquiry and 'ground' it as an emergent property of an iterative, interpretive data analysis process. By rejecting the one-size-fits-all model of logically deduced theoretical accounts of the social world (Glaser \& Strauss 2006, p.4), and proposing theories grounded in assumptions of the relative validity of a plurality of social contexts (Reed 2010, p.35), grounded theory offered bottom-up ways to destabilize assumptions of universality and allow a closer contextual fit between theory and data relating to subjective experience of everyday life. Whilst it originated as a method with a 'foot in both camps' of qualitative and quantitative analysis (Byrant \& Charmaz 2010, p.181), and has a firmly causal leaning, more recent iterations of its style of analysis have included visual, multimodal ways of representing the different iterative stages of analysis (e.g. Knigge \& Cope 2006).

Softening the theory-practice divide differently, ethnography has foregrounded the 'ideological practices' blocking the path of alternative knowledge textualisation practices (Geertz 1988 , p.31), and problematised the issues involved in seeking to construct 'texts ostensibly scientific out of experiences broadly biographical' (Geertz 1988, p.10). Marcus 1987, p.262) foregrounds the need for 'literary consciousness' in the ways ethnographies are written and read, that facilitates the artful integration of multiple voices present in ethnographic interpretive processes.

Significantly, (Marcus 1987) posits such writing practices as requisites of career development in the field, thus spotlighting the always already imbrications of a divergent poetics and politics of knowledge with governance systems, and the deeper questions this raises about how culture operates and the possibilities of criticality.

Introducing the textual inquiry sensibility of the rhizome, in which linear multiplicities operate from a middle, from which they 'grow' and 'overspill', Deleuze and Guattari (1988, p.22) offer new ways of representing the immanence of doing. Defining the rhizome as 'an acentred, nonhierarchical, non-signifying system without
I'd like to nip in the bud any concerns that what I propose is an arbitrary, aesthetic rejigging of a genre convention. It is rather grounded in a serious critique of academic publishing in an era of neoliberal knowledge production.

This touches right at the heart of the Catch 22 situation facing postcritical work in sites of academic governance, since it is foiled at the outset given the moment critique is enunciated it is caught up in textual operations of power and governance. Iformulate this paradox as (a) Don't engage in writing praxis commensurate with theory and increase your chances of publication/ cultural capital, or (b) Do engage in writing praxis

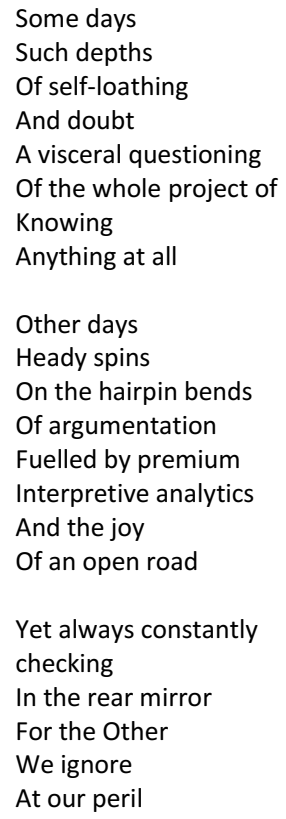


a General ... defined solely by a circulation of states (Deleuze \& Guattari 1988, p.22) the various textual forms it takes are 'plateaus' which can be 'read starting anywhere and can be related to any other plateau' (Deleuze \& Guattari 1988, p.23). Stressing the complexity, and contingency of nomadic social thought (Deleuze \& Guattari 1988, p.26), masked by 'illusory discourses of fixity, stability and identity' (Martin \& Kamberelis 2013, p.670) they point towards alternative forms of representation to embody the proliferating multiplicity of 'becomings' in contingent, productive, systems or mappings. These can 'be drawn on a wall, conceived of as works of art, constructed as political action or as meditation' (Deleuze \& Guattari 1988, p.12). Challenging fixities of positionality, they propose 'assemblages', produced from desires and 'collective enunciations (Deleuze \& Guattari 1988, p.26) as a concept for understanding the complexity of (non)being within scattered yet necessarily connected networks. (Bettez 2014, p.935). An inventive example of Deleuze and Guattari's philosophical consideration of the plateaus of becoming can be seen in Crowley's use in her paper of 'photography, poetry and poetics, self-narration, play and affect' (2010, p.544) to map becoming deaf in the academic workplace.

Whilst honouring these re-settings of the limits of inquiry, to redefine the epistemologies and ontologies of knowledge, and re-cognising how such work in-forms my own assemblages, my interest in this paper is exploring the possibilities for post-critical praxis in interpretive, qualitative research through the apprehension of a history that is other.

\section{Panoptic conditioning of the qualitative researcher as writer}

\section{Research schemata of governance}

In the UK 'today', one example of the latest morphing of technologies of surveillance of scholarly publications, that form part of the 'matrix of calculabilities' (Ball 2013, p.103) in which university subjects are captured, is the REF (Research Excellence Framework 2014). This system of governance, with its parallels of textual performativity, monitoring of outputs, and neoliberal 'countability' of scholarship in the US, EU and the Commonwealth, is mediated by a bibliographical database which uses commensurate with theory to be true to promise of a different future to come and put at risk your chances of publication/cultural capital. Not a strictly either/or scenario it is meant to evoke the complicitous nature of our labours.

To some degree, this whole paper is an exercise in reflexivity about the perspectives and positionality required from us as academics in the writing practices that endorse us. There is no way to completely avoid the pitfalls and double minds of such practices, nor erase our partiality from our subjectivities.

Whilst we usually write and do multiple, messy edits in silence, this silence is not grafted onto our final papers. This adds to the sense of knowledge emerging according to a kind of immaculate conception.

Like many colleagues, I find the REF a prescriptive, undemocratic, and inefficient mechanism for assessing 'excellence'. One reason for this is its
I guess I was always the rebel, living out a rejection of contradictory parental expectations of high academic achievement and a 'good marriage', struggling with $\mathrm{my}$ own various denials and voices, one of which was often hellbent on challenging voices of authority. Naturally identifying with the outsider, the marginal. Bringing all this into my writing, my research, my texts and con-texts. Finding in the 'death of the subject' a welcome invitation to rethink my ethical responsibility to welcome in the other.
Constant selfmonitoring of our performance as academics under the watchful eye of the REF.

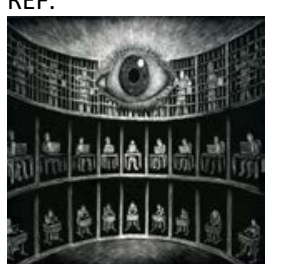


quantitative tools for 'ranking, categorizing, and comparing journals' in order to assess their 'impact factor' (Web of Science: n.d.). In the UK, the rankings awarded to different universities and their departments are used to determine central funding from HEFCE Higher Education Funding Council for Education), and concomitantly the relative status of academics within the academic community. Thus, this instrument of excellence works to orient the desires, aspirations and scholarly writing styles of academic subjects to productive complicity with its quantitative rankings of valuable and worthwhile knowledge (Dean 1999). It can also serve to root the social sciences further in the epistemologies and ontologies of the natural sciences and so, as Pascale argues (2016, p.223) 'limit paradigmatic innovation [...] at the expense of qualitative research itself'. Clearly, if we let scientific rhetoric put the 'ethical' and 'critical' in their place in order to legitimate our status as independent observers of 'the real', and if we choose to internalise scientific reasoning styles as normality, this is not very helpful.

Instead, if in line with Foucault (1990) we understand power relations to depend on multiple points of resistance, and locate this resistance in ethical practices of the self (Foucault 1987), that constitute the 'virtue of critique' (Foucault 1997), then the possibility of resistance and criticality exists, but is located in the materiality of the micro practices of writing/representing rather than in the objective, passive voice subject of scientific discourse.

Constraints and openness of power/knowledge As Foucault helps us to understand, to have claim to an author-itative identity in the centring force-fields and always-already ontologies and epistemologies of Western reason, we need to internalise and work productively with the tightly monitored surveillance mechanisms of scholarly knowledge production (con)texts. By accepting these constraints, we become visible as academics within the levels and hierarchies of discourse, but risk having our criticality eroded. Conversely, by stepping towards the outside of the regulated and monitored spaces of the institution to dance to a different tune than that of the hegemonic and homogenising practices of academic discourse, we can mitigate or invalidate our legitimacy as knowledge producing subjects. Hesitations and imposition of rather arbitrary top-down criteria, such as 'impact', which tends to destroy creativity and promote conformity. [Note: See Martin (2011) for his characterisation of the REF as a Frankenstein monster]. Perhaps in our concern as critical academics to protect the independence and resistance of the university and its academics, we need to prioritise making the complex, ideological nature of the materiality of our texts more explicit. A stance which Willinksy neatly summarises as 'putting our words where our mouths are' (2011,p.131).

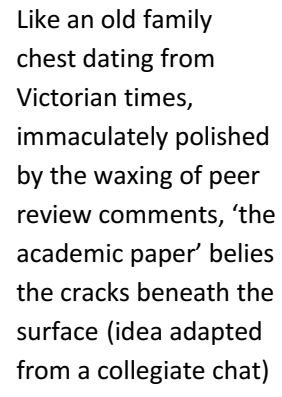

Having stated my intention 'to unsettle' in the abstract, I am aware some readers may find my failure to conform frustrating or unappetizing. Yet my part in this debate requires me to challenge certain established givens, even if it means some may prefer not 
anxieties about testing the limits of dominant textual practices of knowledge production are therefore understandable. The status and very livelihood of an academic hinges upon their publications, as witnessed by the slightly dated adage 'publish or perish', and the content and form of those publications are required to strictly conform to academic and disciplinary presentation norms and ideologies (Billig 2003).

Yet, my point here is that if, as 'subjects of form' (Foucault 1984, p.290), we are to con-test the politically inflected 'truth games' of discursive texturings and renderings of science (Foucault 1984) in a way commensurate with a poststructuralist understanding of the critical and ethical we need to engage with the risk of illegitimacy, and deploy our freedom as subjects of scholarly governance in 'the art of not being governed quite so much' (Foucault 1997, p.45). Such a 'not so much' expects neither emancipation nor liberation from the con-fines of cultural knowledge since there is no exterior to its mechanisms of selection, resistance and repression. Rather, it places some small hope of change in the relation of social forces through unsettling of a pure, privileged space of the reader/writer gaze. In this paper, with the textual goal of making visible what a post-critical writing praxis might look like, the 'not so much' is represented via a format and styles of writing intended both to consent to and resist certain conventions of objectivity, precision and clarity which embody and circulate the cultural and epistemological values of Western reasoning (Turner 2011, p.67). By attending to the margins, absences and subjectivity of social science knowledge production we can produce forms of 'epistemic friction' (Pascale 2016, p.224) between different construals of knowledge.

Though wary of overly neat conceptualisation of the 'why' and 'how' of the three interrelated columns of the text - it is not a question of willing or predicting their interpretation - I propose the reader view them as three, not entirely fixed 'I's, or agencies of discourse, which constitute the subject of knowledge via a labour of 'care of the self' and maintain the space of this inquiry differently. The first column organises particular sets of statements and claims according to the coherencies and criteria of 'truth'. The second operates an opening up of the first through a reflective re- to partake.

There is a sense in which my engagement with the subject matter of poststructuralist thinking is meant to convey an openness to the possibility that the textual practices that have employed us till now might be found wanting.

Pierre Huyghe's neon epigram confounds the transcendental notion of authorship in the 'not so much' of 6 words

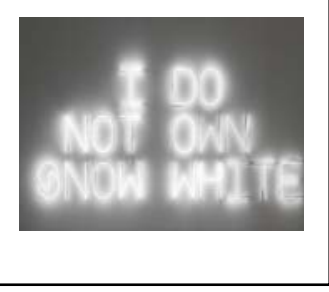

Such pleasure in writing beyond the margins as well as within. $A$ destructuration of the academic self which feels almost erotic. Reason hides its desires and unconscious impulses. Like good academic subjects we do the same. 
reading of that 'truth' in after-words that extend the referents of the first column and point to more personal, conversational constitution of the subject of 'truth'. The third enacts an-other, messier, more fragmented trajectory of individuation which brings into the paper other conventionally silenced components of the process of inquiry that include: reflexive statements on the process of writing 'truth' differently; more poetic, creative linguistic conventions to reflect upon the silenced subjectivities of knowledge production; reference to the other of the visual and art intended again to de-parse from the centre. In each column, dynamics of repression operate to exclude and silence the other, and in each the 'I', be it tacit or explicit, is an empty signifier with the agency to articulate, operating within aporiatic fields of discourse. However, through a small, local politics of plurality, a critical and ethical attention to other momentarily releases knowledge and the reader gaze from standard logics of 'truth'.

The promise of the unexpected in our temporary freedoms of writing

This is just one formula for writing differently and re-thinking the postpositivist con-texts of discovery (Reed 2010). A stylistic experiment in which the history of rhetoric features, in a way intended to ensure that the text itself, not simply its logic and arguments, point at the contingency of all authoritative knowledge claims and bring into scrutiny the limits theory/practice have for resisting business as usual. Qualitative research already produces active encounters between the meaning of the researcher and the subjects they are studying (Reed 2010), and there have been previous examples of doubling or splitting the text, notably in the split text of Lather and Smithies 'troubling' work (Lather \& Smithies 1997), or Lather's project of 'a double(d) science' where 'theoretical complexities are used as tools to make a material difference' (Lather 2009, p. 342) by introducing ambiguity and uncertainty into rationality. Similarly, when taking a critical stance towards academic literacies, Lillis (2011) uses the concept of juxtaposition in order 'to open up debate about the kind of semiotic tools that should be valued in the academy', both in relation to student assessment writing and scholars working on publications' (Lillis 2011, p.424). Using Bakhtinian notions of intertextuality, heteroglossia and dialogue, and a text split into
A double reading of the canon from within that intervenes yet assumes no end to the repetitions of discourses of reason.

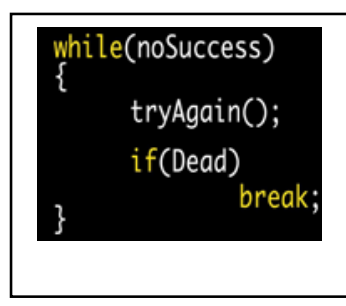

Gazing beyond the surface of the 'page' to the code and complex algorithms that pro-duce it.

Such reconfigurings of interpretation provide an ethical orientation towards subjects and subject matter as they/it emerge(s). Yet nothing can exhaust the productivities of the interpretation of truth which are a characteristic of human existence.
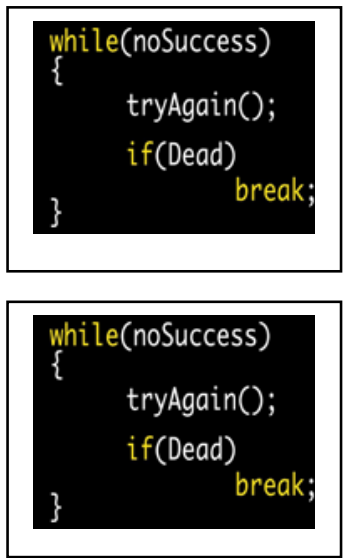
three columns, her aim is to legitimate new textual and ideological goals of polyphonic academic writing (Lillis 2011, p.413) as evidenced in her text split into three columns. However, whilst her critical intention of revealing the dynamic 'openness and incompleteness' (Lillis 2011, p.423) of the centred, conventionalised pages of academic writing resonates with the intention of this paper, and her use of simple word processing tools to mediate this intention inspired mine, her account of the dialogic writing subject does not put in question the 'I' of the writer, nor problematise the subject of knowledge's limited relevance to the construction of 'truth', nor incorporate images and more poetic linguistic conventions that uncover the presence of the ambiguity of affect, fiction and the visual in scientific processes, that are largely hidden in objectivist orderings of reason. Thus, whilst through Bakhtin she posits the presence of a heterogeneous 'other' in cultural production and uses this to renew scripted conventions of academic rhetoric, she paradoxically infers an ahistorical writing subject independent from the play of difference across all three columns, be they scholar or student, and returns to an epistemology which separates the subject from knowledge production.

Premised on the historicity of knowledge production and the assumption of all subjects' imbrication in the textual operations of power and governance, this paper is proposed as a useful addition to such prior work. One that might prompt a reconceptualisation of qualitative research subjects as decentred ethical-political subjects who minister to 'the politics of ourselves' (Milchman \& Rosenburg 2011, p.4) from within the fabric and structures of knowledge. By committing to less tidy, less linear practices of writing, full of tensions and self-conscious variegation, and by linking the intelligible with an intelligible yet to come, we might momentarily recover a place of criticality and ethics in the received schemata of Western knowledge, and do productive damage to dualistic accounts of interpretation.

Finally, with regard to the potential outcomes of such a shift in the stylistics of the qualitative researcher outlined in this paragraph, it seems pertinent to excavate here one of the adjectives in the list of three that characterise 4 star quality work in the REF 2014, 'Quality that is world-

The migration of most words and meanings to the left hand column of the page, which contains the main arguments of this paper, leads to the serendipitous outcome of plenty of blank space in which to imagine what is not/or might be spoken in less determinate coordinations of knowledge.

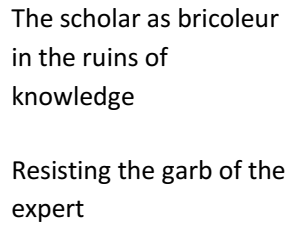


leading in terms of originality, significance and rigour' (my italics). Interestingly, the question has not yet been asked as to what constitutes originality at the level of the stylistics of academic rhetoric used in a research paper, and perhaps it is by asking this question in the materiality of our own writing practices that we can destabilise the academic subject as an unexamined universal position of authority. Such practices both contest and are aligned with current trends in the knowledge economy.

\section{Re-turning to theory - waiting for the writer}

To help me theorise and conceptualise a practical writer's stance that could support and inspire a critique of mainstream language tactics in academia, and by extension the ontoteleological principles of reason the REF and similar systems of governance are grounded on, I first turn to the resource-fullness of just some of Derrida's terms which I consider of perennial relevance for finding ways to intervene in normative academic grammars and subject positions.

By its very name, the most famous of these, deconstruction, signals an invitation to critique the canonical texts and institutions that are our social 'structure'. Recognizing, like other critical social theorists, that no subject can ever be free from the external conditions and constraints that are our heritage, Derrida works to re-read from within what he calls 'the event' of writing (Derrida 1988) so as to lay bare the ideologically loaded humanist myth that writing is a fixed, centred site of interpretation of meaning or truth which organises knowledge and its subject in 'a plenitude that [is] present to and identical within itself' (Derrida 1988, p.56). In order to conceptualise the operation of deconstruction of the problematic truth value of the discourse of Western human sciences premised on a centre, without postulating an Other, Derrida replaces the philosophical notion of an intentionality with telos by an intentionality without telos that is 'always differing and deferring' (Derrida 1988, p.57). Thus, for Derrida, the 'event' of writing irrupts within an 'unnameable movement of differenceitself that I have strategically nicknamed trace, reserve or différance' (Derrida 1998, p.93).

Another condition of the event of writing is that it 'belongs to a perhaps that is in keeping not with the possible but the impossible' (Derrida
Western epistemologies carry hidden within them identity mechanisms which work to portray the passive voice of reason's rhetoric as a singular, objective expert who, by historical default, is male. Feminist and critical academics work to deconstruct such fixed understandings of authority and the neutrality of language. As Loxley (2007, p.43) puts it, they see the scene of writing as offering 'an ethical openness to other voices' which takes responsibility for the 'limits and possibilities' of their and the others' co-construed worlds. Spivak's work in this regard focuses on the aim of 'letting the subaltern speak'.

Clearly, a principal aim of all postmodern theory and praxis is to intervene in modernity's ways of conceiving reality as unitary, universal, linear and hierarchical. In this con-text, rather than seeing
There is no future present

Only a future past

The question 'To be or not to be', from

Shakespeare's Hamlet, springs to mind here as a simple, potent evocation of the spirit of Derrida's deconstruction. A question always asked, but that can never fully be answered.

The critical concerns leading to Magritte's contradiction of commonsense understandings of reality in his artwork below seem to me to resonate with Derrida's indications for making new future operations possible.

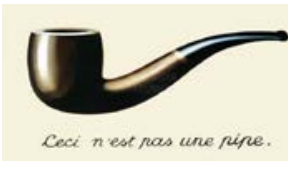

Of course, it is Foucault rather than Derrida who explores Magritte's 'This is not a pipe' painting as an example of representation that challenges the thingness of things, in his book whose title exactly echoes that of the painting. Yet here, for me, the image captures Derrida's the spirit of Derrida's critique of objectivity and the supposed plenitude of science's accounts of the truth. 
2005, p.22) which ensures it has a force 'irreducible to the force of a performative' (Derrida 2005, p.22) and so keeps open the possibility of a future which might be different. Furthermore, for Derrida it is not the event of writing that is the limit of meaning, but rather the deferred temporality of critical re-reading that affords the last instance of interpretation of meaning (Derrida 1988, p.21). In this paper I plug into Derrida's invitation not to neatly set apart the problems of philosophy from the problems of writing by including format as part of the semiotics of the latter, since it too plays a part in closing down the different times and subjectivities of the research process to reproduce Western reason's cohesive web. In this sense, the second two columns are intended to convey structurally and metaphorically the differing and deferring of meaning that takes place in different times, places and discourses relating to the spaces of an inquiry.

Within his own writing Derrida exemplifies a deconstructive 'ethos of writing and thinking'(Derrida 2004, cited in Lawlor 2007, p.116) that challenges textual orthodoxies in a number of ways. Some of his rethinking of the event of writing also takes place at the level of the page, format and margins, such as his 1974 work, Glas (Derrida 1974[1986]), where he writes in two columns, with the left devoted to a reading of Hegel's 'objective spirit' and the right devoted to a reading of the French novelist-playwright Jean Genet, both of which readings inter-resonate with the other. In the scene of his writing, the impure relational and temporal spaces between the opposite poles of Hegel's dialectical syllogisms, and the literary devices and $\mathrm{f}(\mathrm{r})$ ictions of Genet form part of the pre-text, con-text and textual practices Derrida uses to fragment the plenitude of the subject and telos into the dispersed 'remains of a signature'(Derrida 1974[1986], p.4). An event of writing that en-acts and en-codes the death knell (French translation: glas) of knowledge, its wordplay, re-spellings, re-writings, remixings and textual re-configuring of conventional form and content provide rigorous, original examples of textured uncouplings of knowledge from its calculable and ahistorical habits, that disrupt the horizon of what is to come. Other examples elsewhere of Derridean de-constructive tropes include changing a word spelling to redefine previous terms e.g. 'différance', or cross out the word 'is' with an X ethics as comprehensive, uniform rules that, as Bauman puts it, 'can be injected into human conduct' (1993, p.6, postmodern and poststructural theorists see ethics as a form of ethicalpolitical alertness and resistance to the simplifying and homogenising surveillance systems of capitalism and modernity which act to perpetuate 'the satisfactory narratives and complete outcomes' of academic discourse (Bowman 2014, p.7). What I like and find useful in the writing of Foucault, Derrida and Spivak is the creative way that, though all working within the reigning orders of knowledge, they elude categorical imperatives and 'is-ness' by, inter alia, deploying allusion, paradox and metaphor. Their openended delineations of the space of inquiry provide rich heuristic for finding my own ethos of writing. ruins' (Readings 1996) I
So much of our subject agency in the field of the historical present is acted out in a mode of standing to attention, our heads full of serious knowledge equipment, ready for parade, attack and defence. Spivak's wordings invite and encourage us to look beyond the ordered ranks of reason and explore being 'at ease' in less regimented spaces.

With regard to what 'truthfulness' is, perhaps nobody has ever been sufficiently truthful.

Nietszche: Aphorism 177 
to de(p)lete its affirmative power, or be poetic in register as in his evocation of the feelings associated with altering the material conditions of writing;

... night begins to lighten a little at the moment when linearity - which is not loss or absence but the repression of pluri-dimensional symbolic thought relaxes its oppression because it begins to sterilize the technical and scientific economy it has long favoured' (Derrida 1998, p.93)

This inclusion of the 'critical' not as an absolute value, or form of dialectic in argumentation, but as a graphical and layout feature of academic writing is what can 'perhaps' generate a matrix shift that eludes the repressive nature of 'the line' at the same time that it reveals tradition's subjection of rationality to the line (Derrida 1998, p.86). Enjoining my activity to that of Derrida through a 'care of self', I similarly use the margins, wordplay, poetic register, and the play between gaps and text as providing room for 'rhetorical (...) effects which are also political strategies' (Derrida 2003[2005], p. 89), since they sign-ify a different future to come and a 'stance of survival coming through all the old and tired features' (Derrida 2003[2005], p. 89). As a different technology of living and thinking, such a care of the self requires selfexamination, draws attention to dominant modes of social production, and offers divergent ways of giving form to knowledge.

In the con-text of formulating tools of deconstruction intended to systematically question plenitude, and in a critical reading of the work by Levi Strauss, The Raw and The Cooked, which explores the discourse of myth, Derrida proposes bricolage as 'critical language itself' (Derrida 1986, p.486), since the bricoleur remains true to the (broken) promise of the usefulness of the instruments at hand whilst adapting them when and where it seems necessary. Recognising the need to go beyond the potential contradictions in this doubled use of the empirical and bricolage, whereby the bricoleur critiques the discourses of positivism yet nevertheless ends up colluding with them in their rhetoric, which in turn becomes open to critique, Derrida advances the concept of freeplay. A surplus of signification that disrupts presence, freeplay updates and critiques the feel there is an ethicopolitical onus on me/us to resist the conformist cultural production of scholarly works that exclude the complexity of resistance. Not to do so only repeats the historicity of the Western university. It is by dis-aggregating the logics of knowledge's writing and reading that I/we can unsettle our privileged location and understanding of what it means 'to be critical'. According to Derrida, it is the ethical and political responsibility of the Humanities to submit the university and themselves to an interrogation of the grounds of their own meaning (Peters \& Trifonas 2005, p.9).

Underpinning Derrida's take on bricolage is the assumption there is no privileged reference point from which to point to an origin of discourse. Hence, freeplay, where totalization has no meaning and there is no fixed locus to writing. 
impossibility of the finite totality of the field proposed by the engineer's view of the relationship between the sign and the signifier, and instead proposes 'the field is in fact that of freeplay, that is to say, a field of infinite substitutions in the closure of a finite ensemble' (Derrida 1986, p.490). To explain the movement of freeplay Derrida devises the concept of the supplement, which by substituting itself for the absence at the heart of the sign, gives the appearance of plenitude though it covers a void (Derrida 1998, p.144, Derrida 1986, p.490). In the double critical project of building the new with the debris of the old proposed by bricolage, Derrida argues the route to be taken is via two interpretations of structure and sign. In this double reading the first 'seeks to decipher, dreams of deciphering, a truth or origin which is free from freeplay. The other, which is no longer turned towards this origin, affirms freeplay and tries to pass beyond man and humanism' (Derrida 1986, p.492).

Transposing this double gesture which bridges the shifting spaces of the conditions of possibility to the site of the university which ought to be granted 'an unconditional freedom to question and to assert' (Derrida 2005, p.11) if research into the 'truth' is to be conducted, to oppose those corporate and ideological powers which limit a democracy to come by imposing end-oriented constraints on the language of knowledge. This paper is a nod at that ethical responsibility.

As demonstrated in this paper, my supplement to Derrida's alternative to science and philosophy's 'closure of the epistémè' (Derrida 1998, p.93) which points beyond the walls of presence to a 'nether world of what could take place tomorrow' (Willinsky 2005, p.133), is simply to re-iterate his pointing to the blank parts of the text in his use of alternative wordings, presentation and layout. Each paper that takes the step of opening itself to this space of blankness serves to illustrate the place of the critical within the historical present of these systems of governance to which we take recourse, as well as to bring into question the narrowness and weakness of systems such as the REF which subjects our scholarship to corporate-like measures of quality of production.

To extend Derrida's theoretical mapping of
Understanding the meaning

or 'outcomes' of writing

not from the author's

intention, but from the play

between the different parts,

agencies and

interpretations of the text is

one way to resist the notion

of knowledge as subjective

or objective, and call into

question the relation

between the subject of

qualitative research and

her/his/our writing

technologies.

Toppled by shaky ground into agonisms of meaning the subject floats in a new signifying economy where they are not so much an 'I' as a process of change.
My earlier study and practice of fine art still inhabits me as an embodied awareness of the possibilities of fragmenting frames to reveal the fictions of representation so as to create non-canonic understandings of the value of 'art'. However, despite art re-framing its aims to those of challenging and transforming society, markets and institutions have simply rebranded most of these new practices to create and protect art's value as capital. Thus, the paradox of all critical practice, since it is destined either to be legitimized or to be marginalised. This does not mean, however, that we should set aside our attempts to interrupt historicity. 
tools to de-construct the social and economic organisation of scientific and philosophical discourse that frame us, I briefly now turn to Spivak's critique of the politics of translation (1993). This work, premised on feminist resistance to homogenising translations of 'foreign feminists' (Spivak 1993, p.182) that can mean work written 'by a woman in Palestine, begins to resemble in the feel of its prose, something by a man in Taiwan' (Spivak 1993:ibid.) targets the opacity of the majority of texts translated into the world's majority language English' (Spivak 1993:ibid.) whose meaning-translation Spivak faults for failing to fully surrender to the text, so as to make translation 'the most intimate act of reading' (Spivak 1993, p.183). Whilst this paper does not directly address translation, I find Spivak's challenge to be alert to the blunt, political mechanisms of centredness that can blind us to the murkiness behind the purported 'transparency' of the world's dominant language of science - English - gives useful witness to 'other' ways of knowing subalternised and silenced through a governmentality which standardises and commodifies knowledge for its use in competitive, institutional and disciplinary market practices. More practically, capitulating to a jouissance in our intimate acts of reading and writing is proposed as one way to evidence and re-embody the ideologically silenced other.

Following the poststructuralist staging of agency of the critical academic, which Spivak characterises as positioning the agent within 'a three-tiered notion of language (as rhetoric, logic, silence)' (Spivak 1993, p.181), if we are to know critically and ethically then we need to 'swerve from the straight line of western reasoning' (Spivak 1993, p.179), to acknowledge that intention is never fully present to itself, and give clues to where the subject loses its boundaries. More specifically and practically, Spivak suggests that we can try to 'enter or direct' the staging of agency 'as one directs a play, as an actor directs a script' (Spivak 1993, p.181). Developing upon this analogy, Spivak stipulates that rather than using logic that 'allows us to jump from word to word by means of clearly indicated connections' (Spivak 1993:181), we need to work in 'the jagged relationship between rhetoric and logic' (Spivak 1993:ibid.), to explore 'the silence between and around words' (Spivak 1993:ibid.).
Rebecca Horn's Pencil Mask offers an idiosyncratic reading of how the subject's agency is 'neither free nor natural' (artmag 2004), but caught up in the power and governance of 'writing technologies' leading to fluctuations between object and subject ... with meaning emerging somewhere in movement's gaps.

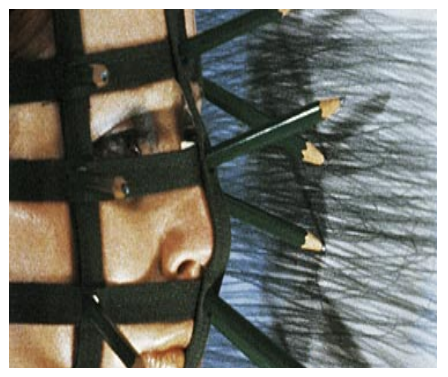

How can we compensate all those whose (ways of) life we took/take from them?

What greedy organs our brains are.

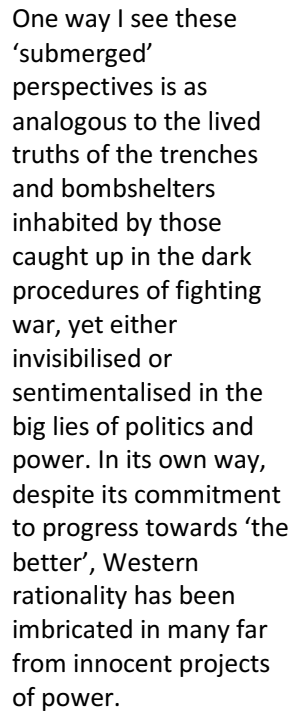


It is this that ensures that that 'the agent can act in an ethical way, a political way, a day-to-day way; so that the agent can be alive, in a human way, in the world' (Spivak 1993:ibid.).

All three authors offer ways of rethinking the divisions by which academia produces, sustains and parameterises itself, and hence for attuning the textual practices of qualitative research more closely to its historicity and future which has nowhere particular to go. By enacting and pointing to ways to make performative breaks with the limits of certitude and the sovereign spaces of the printed page, they all re-iterate the political issues at stake when taking the decision/or not to introduce a different ethos and poetics into academia. One which goes beyond neoliberal structurings of knowledge and academic subjects. As a 'take-away' list of possible reworkings of the traditional limits of scholarly rhetoric such that the 'post-critical' be a condition of our writing, I here offer a brief recap of the ideas of Foucault, Derrida and Spivak as possible heuristics for developing a new ethos of writing.

Foucault:

Through an ethics of care of self, act to be less governed by hegemonic constraints

Derrida:

Derrida/Spivak:

Spivak:
Disrupt and deconstruct plenitude using the critical stance of the bricoleur and interpretations of interpretations Look to the blanks, jagged margins, and silences around our words to pass beyond repressive linearity that shuts the door on heterogeneous, pluridimensional ways of knowing Bring ethics, critique and life back into our wordings of the world through more conscious directing of our agency in our knowledge scripts and more intimacy in our acts of writing-reading
Whilst none of us can ignore the hidden 'rules of the game' (Lillis 2011, p.409) of academic writing, I have sometimes found myself despairing at how often this may simultaneously encourage academic rigour and critical practice, yet also generate replications of a genre performed from an anxious desire to conform and so do well. I know only too well the struggles (and pleasures) when trying to produce arguments and analysis of data or texts which are not stifled by the need to fit within the ambit of academic norms. My critical convictions have always convinced me there
I find Braque's cubist perspective of 'A woman and her guitar', that resists final determinations, a more fitting representation of me as (academic) subject than thumbnail corporate photo on university website.

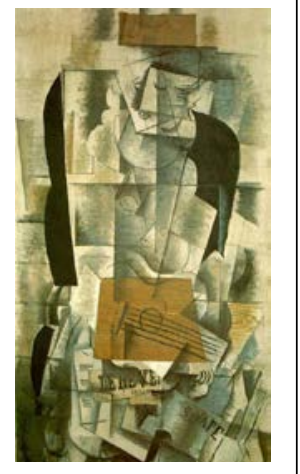




\section{Knowledge is not an end but a beginning}

Whilst neither the term 'post-critical', nor its practice as ethico-political resistance coterminous with the material practices of writing knowledge, have the power to transform the social logics of the vanishing presents which constitute us, this does not detract from our responsibility as post-critical qualitative researchers to occupy knowledge differently. The simplest of our typing technologies afford an accessible, productive way to blur the traditional outlines of the cultural product of a critical, scholarly paper. Rather than damaging the specificity of the former, I would argue use of such tools makes the plural, dynamic, uneven complications of authoritative knowledge more visible, and hence, paradoxically, adds to the 'originality' and rigour of its critical intent and, paradoxically, aligns with this key signifier of REF excellence. It also introduces different notions of epistemological impact. In the light of such a hope, I offer this ecumenical rereading and writing of the 'post-critical', as one possible way to play with knowledge without exclusively deploying a linear mode so as to reform the subject. was something wrong with the structures of academic knowledge, even if I could not quite put my finger on what that was.

Authors such as Lillis

(2011), Lillis and Scott

(2007), Street (1984), Lea

and Street (1998),

Bazerman (1988) and Ivanič $(2004,1998)$ have all re-read conventional understandings of the precoded genres of disciplinary writings to argue for radical reorderings of academic rhetoric that allow for the abstract and silenced subject and other of knowledge texts to reveal some of their plural, interrupted ways of producing meaning.

\section{Acknowledgements}

I would like to thank Theresa Lillis for her approaches to re-legitimating academic writing practices which inspired the textual practices in this paper and Mary Deane for her collegiate comments on first versions of this paper.

\section{References}

artmag (2004) The Movement of the Body, the Substance of the Self. Accessed 6.07.17 at: http://dbartmag.de/archiv/2004/e/8/2/284.html

Ball, S. (2013) Foucault, Power and Education. London; New York: Routledge

Ball, S. (2016) Neoliberal Education? Confronting the slouching beast. Policy Futures in Education. 14(8), pp.1046-1059

Bauman, Z. (1993) Postmodern Ethics Oxford: Blackwell

Bazerman, C. (1988) Shaping Written Knowledge. Madison, Wisconsin: The University of Wisconsin Press 
Ben, R. (2011) The Research Excellence Framework and the 'Impact Agenda': are we creating a Frankenstein monster. Research Evaluation, 20(3), pp. 247-254

Bettez, S.C. (2014) Navigating the Complexity of Qualitative Research in Postmodern Contexts: Assemblage, Critical Reflexivity and Communion as Guides. International Journal of Qualitative Studies in Education, 28(8), pp.932-954

Billig, M. (2003) Critical Discourse Analysis and the Rhetoric of Critique. In: Weiss, G. \& Wodak, R. (eds.) (2003) Critical Discourse Analysis: Theory and Interdisciplinarity. Basingstoke: Palgrave Macmillan, Part1:2, pp.35-46

Bowman, P. (2014) Autodidactics of Bits: Adrian Rifkin's [Rancièrian] Cultural Studies \& the Partition of the Pedagogical. Chapter 7 in: Arnold, D. (ed.) (2014) Intersubjective Encounters: Reexamining the work of Adrican Rifkin. London; New York: IB Tauris. Accessed 13.08.15 at: https://www.academia.edu/703196/Autodidactics_of_Bits_Adrian_Rifkins_Rancierean_Cultural_Stu dies and the partition of the pedagogical

Bryant, A. \& Charmaz, K. (2010) The Sage Handbook of Grounded Theory. Los Angeles; Calif.; London: SAGE

Crowley, V. (2010) A Rhizomatics of Hearing: Becoming Deaf in the Workplace, and Other Affective Spaces of Hearing. Discourse: Studies in the Cultural Politics of Education, 31(4), pp. 543558

Dean, M. (1999) Governmentality: Power and Rule in Modern Society. London; Thousand Oaks; New Delhi: SAGE Publications

Deleuze, G. \& Guattari, F. (1988) A Thousand Plateaus: Capitalism and Schizophrenia. London; New Dehli; New York; Sydney: Bloomsbury

Derrida, J. (1974[1986]) Glas. Translated from the French by John Leavey and Richard Rand, Lincoln, NE: University of Nebraska Press. Accessed 18.06.17 at: https://monoskop.org/images/d/d5/Derrida_Jacques_Glas_1986.pdf

Derrida, J. (1986)'Structure, Sign and Play in the Discourse of the Human Sciences'. In Robert Con Davis (ed.) Contemporary Literary Criticism: Modernism Through Post-Structuralism. New York \& London: Longman

Derrida, J. (1988) Limited Inc. Translated from the French by Jeffrey Mehlman and Samuel Weber. Evanston, IL: Northwestern University Press

Derrida, J. (1998) Of Grammatology. Corrected ed. Translated from the French by Gayatri Chakravorty Spivak. Baltimore: John Hopkins University Press

Derrida, J. (2003[2005]) Rogues: Two Essays on Reason. Translated from the French by PascaleAnne Brault and Michael Naas. Stanford, Calif.: Stanford University Press

Derrida, J. (2005) The future of the profession, or the university without condition: (Thanks to the "Humanities," what could take place tomorrow. In: Trifonas, P.P \&Peters, M.A. (eds.) (2005)

Deconstructing Derrida. New York; Basingstoke: Palgrave Macmillan

Fairclough, N. (1992) Discourse and Social Change. Cambridge: Polity Press 
Flow, J. (2006) Genre. NewYork; London: Routledge

Foucault, M. (1972) The Archaeology of Knowledge and the Discourse on Knowledge. New York: Pantheon Books

Foucault, M. (1984) 'The Ethics of The Concern of the Self as a Practice of Freedom'. In: Rabinow, P. (ed.) (2000) Essential Works of Michel Foucault 1954-1984 - Vol. 1 Ethics, Subjectivity and Truth. London: Penguin

Foucault, M. (1987[1984]) The Use of Pleasure: The History of Sexuality: 2. Translated from the French by Robert Hurley. London: Penguin Books Ltd.

Foucault, M. (1990[1976]) The Will to Knowledge: The History of Sexuality: 1. Translated from the French by Robert Hurley. London: Penguin Books Ltd.

Foucault, M. (1997) What is Critique? In: The Politics of Truth. English Translation. Translated from French by Lysa Hocroth \& Catherine Porter. In Dits et Ecrits for original French. Los Angeles: Semiotexte. Accessed on 10.07.2015 at: http://anthropos-lab.net/wp/wpcontent/uploads/2011/12/Foucault-Critique.pdf

Glaser, B.G. \& Strauss, A.L. (2006[1967]) The Discovery of Grounded Theory: Strategies for Qualitative Research. New York: Aldine Transaction.

Geertz, C. (1988) Works and Lives: The Anthropologist as Author. Stanford; CA: Stanford University Press

Hannam, T.H. (2009) Neoliberalism, Governmentality and Ethics. Foucault Studies. 6, pp.37-59

Hébert, L. (2011) The Functions of Language. In: Louis Hébert (dir.), Signo [online], Rimouski (Quebec). Accessed on 15.08.16: http://www.signosemio.com/jakobson/functions-of-language.asp.

Ivanič, R. (1998) Writing and Identity: The Discoursal Construction of Identity in Academic Writing. Amsterdam; Philadelphia: John Benjamins Publishing Company

Knigge, L. \& Cope, M. (2006) Grounded Visualization: Integrating the Analysis of Quantitative and Qualitative Data Through Grounded Theory and Visualization. Environment and Planning, 38(11), pp. 2021-2037

Lather, P. \& Smithies, C. (1997) Troubling the Angels: Women living with HIV/Aids. Boulder, CO: Westview Press

Lather, P. (2009) 2007 Kneller Lecture, AESA. Getting Lost: Social Science and/as philosophy. Educational Studies. 45(4), pp.342-357

Lather, P. (2013) Methodology-21: what do we do in the afterward? International Journal of Qualitative Studies in Education, 26(6), pp. 634-645

Lawlor, L. (2007) This is not sufficient: an essay on animality and human nature in Derrida. New York; Chichester: Columbia University Press

Lillis, T. (2011) Legitimizing Dialogue as Textual and Ideological Goal in Academic Writing for Assessment and Publication. Arts and Humanities in Higher Education, 10 (4), pp.401-432 
Lillis, T. \& Scott, M. (2007) Defining academic literacies research: Issues of epistemology, ideology and strategy. Journal of Applied Linguistics. 4(1), pp.5-32

Loxley, J. (2007) Performativity. New York: London: Routledge

Marcus, G. (1987) Ethnographic Writing and Anthropological Careers. In: Clifford, J. \& Markus, J.E. (eds.) (1987) Writing Culture: The Poetics and Politics of Ethnography. Berkeley; Los Angeles; London: University of California Press. Accessed on 3.07.17 at:

https://repositorio.ufsc.br/bitstream/handle/123456789/1362/clifford_writting.pdf?sequence=1

Martin, A.D. \& Kamerelis, G. (2013) Mapping not Tracing: Qualitative Educational Research with Political Teeth. International Journal of Qualitative Studies in Education, 26(6), pp.668-697

Milchman, A. \& Rosenburg, A. (2011) Michel Foucault: An Ethical Politics of Care of Self and Others. In: Zuckert, C.H. (ed.) Political Philosophy in the Twentieth Century: Authors and Arguments. Cambridge: Cambridge University Press, pp.228-237

Pascale, C-M. (2016) Discourses of the North Atlantic: Epistemology and Hegemony. Qualitative Inquiry, 22(4), pp.219-227

Peters, M.A. \& Trifonas, P.P. (2005) Introduction. In: Trifonas, P.P \&Peters, M.A. (eds.) (2005)

Deconstructing Derrida. New York; Basingstoke: Palgrave Macmillan

Readings, B. (1996) The University in Ruins. Cambridge; Mass; London: Harvard University Press

Reed, I. (2010) Epistemology Contextualised: Social-Scientific Knowledge in a Post-Positivist Era. Sociological Theory, 28(1), pp.20-39

REF 2014. Accessed 20.07.16 http://www.ref.ac.uk/

Spivak, G.C. (1993) Outside in the Teaching Machine. New York; London: Routledge

Spivak, G.C. (2016) Critical Intimacy: An Interview with Gayatri Chakravorty Spivak. LA Review of Books. Interviewer: Paul Grayson. Published 29 July 2016. Accessed on 1.08.16 at: https://lareviewofbooks.org/article/critical-intimacy-interview-gayatri-chakravorty-spivak/\#!

Turner, J. (2011) Language in the Academy. Bristol, Buffalo, Toronto: Multilingual Matters

Willinsky, J. (2005) Altering the Material Condition. In: Trifonas, P.P \&Peters, M.A. (eds.) (2005)

Deconstructing Derrida. New York; Basingstoke: Palgrave Macmillan

Web of Science. Accessed on 21.07.16: http://wokinfo.com/essays/impact-factor/. 